\title{
Development of the Dribble Exercise Model in Soccer of Fpok Students in IKIP Mataram
}

\author{
Herman Syah ${ }^{1^{*}}$, James Tangkudung ${ }^{2}$, Ahmad Sofyan Hanif ${ }^{3}$ \\ ${ }^{1}$ Sports Education Doctoral Program, State University of Jakarta, Jl Rawamangun Muka, East Jakarta, Indonesia \\ hermansyahikipmataram@gmail.com \\ ${ }^{*}$ Corresponding Author
}

How to Cite: Syah, H., Tangkudung, J.,, Hanif, A., S. (2019). Development of the Dribble Exercise Model in Soccer of Fpok Students in IKIP Mataram. International Journal for Educational and Vocational Studies, 1(4), 286-289

\section{ARTICLE HISTORY}

Received: 18 May 2019

Revised: 3 June2019

Accepted: 2 August 2019

\section{KEYWORDS}

\section{Model;}

Practice;

Dribble Exercise Model;

Soccer Game;

\begin{abstract}
The purpose of this study was to develop a dribble training model for soccer games of fool students in IKIP Mataram. The method used in this study is the research methodology and development of Borg and Gall, which consists of ten stages. The final results of this research and development are written in a handbook on dribble training models for soccer games for those that have been evaluated by experts, trial and revision, and their effectiveness has been tested. The instruments used in this development research were questionnaires and the Instrument Test dribble. The design of this study uses research \& development (R \& D) research methods from Borg and Gall in the form of qualitative and quantitative approaches used to reveal the second objective, with a pre-experimental research design in the form of the one-group pretest-posttest design that looks for significant differences in the exercise model before and after being given a training model. Where the analysis of data research uses the t-test with a significance level of 0.05 , Therefore, the effectiveness of the development of the model develops a model of dribble training on the basis of improving skills in dribble giving a reference so that this training model can be used to do variation training in implementing football dribble on students of Fool in IKIP Mataram.
\end{abstract}

\section{INTRODUCTION}

This research model is used to overcome the gap between basic research and applied research. The gaps encountered usually range from the results of basic theoretical research and the results of practical applied research.. Research and development is a research model used to overcome this gap. The $\mathrm{R} \& \mathrm{D}$ method is one of the research methods that has been widely used in the fields of natural sciences and engineering. In the field of education and especially in the field of sports science, it is a relatively new concept. Science can be considered as a strategy of seeking more or less abstract knowledge called theory.

Dribbling is the ability to dribble from one place to another by still mastering the ball that is useful to avoid the opponent's opponent and to adjust the tempo of the game. Without good dribbling skills, a player will look like a player who has just mastered a few techniques in playing football and is not able to play well.. In connection with this, the achievement of the football club with the characteristics as mentioned above, becomes a separate reference for research material. From the reality, the model of dribble training in football is something urgent and must be realized immediately. This model of dribble training is expected to be the first idea for dribble training,before being developed and disseminated to become one of the alternatives for boosting football performance, both at club, national, regional and international levels. Whereas development is the application of organized knowledge to help solve problems in society including in the field of education.

Research and development ( $\mathrm{R} \& \mathrm{D})$, development research is a research method used to develop or validate products that will be used in education and learning. In the Indonesian Wikipedia it is stated that research and development have commercial interests in relation to pure scientific research and applicative development in the field of technology.

The researcher obtained the results of skill data through the assessment of dribble instruments on soccer games. The implementation of this research model is planned to disseminate (dimensions) products that have been revised so that they have become the final results for soccer coaches through media or discussions and journals to 
be published. As a summative evaluation material, this product will be disseminated to the club/team in NTB especially football in Fool students of IKIP Mataram students in a certain period of time, so that they can assess the effectiveness and efficiency of this product in the training process.

The implementation of this research model is planned to disseminate (dimensions) products that have been revised so that they have become the final results for soccer coaches through media or discussions and journals to be published. As a summative evaluation material, this product will be disseminated to the club/team in NTB especially football in Fool students of IKIP Mataram in a certain period of time, so as to be able to assess the effectiveness and efficiency of this product in the training process. In testing the significance of differences with SPSS 21, then the Kolmogorov Smirnov value for pre-test and post-test of dribble training model in football game (X1) is 0.921 with Asymp. Sig. (2-tailed) $=0.365>0.05$, and (X2) amounting to 0.920 with Asymp. Sig. (2-tailed) $=0.366>$ 0.05 , which means the normal distribution model. The coefficient of the exercise model before and after the dribble training model is given with the game in the football sports branch is 0.887 with $\mathrm{p}$-value $0.00<0.05$, so the conclusion is significant. there was a significant difference in the training model before and after being given a soccer football dribble training model for Fool students of IKIP Mataram.

\section{METHOD}

\subsection{Research design}

Madaus and Kellaghan cite the understanding of the model from the Oxford English Dictionary as follows, that the model is "....a summary, epitome, or abstract of the way a partcular one conceptualizes and describes...”.18 The model is a summary or abstract of a person's method or concept of something. Meanwhile, Sanjaya quoted the opinion of Good and Travers, that: The model is not realistic, but it is a realistic representative developed from the situation. Research and development in this exercise uses the Research \& Development (R \& D) model of Borg and Gall which consists of ten steps, such as: The focus of this research is on the development of a dribble training model on soccer games, so the approaches and methods used in this study are mixed methods research which is combining qualitative and quantitative methods. Of course, this is intended to be able to reach or process all data or information so that a comprehensive explanation will be obtained. While the research method used in this study is the research and development method (research and development) from Borg and Gall, with consideration of the stages of development research put forward quite clearly.

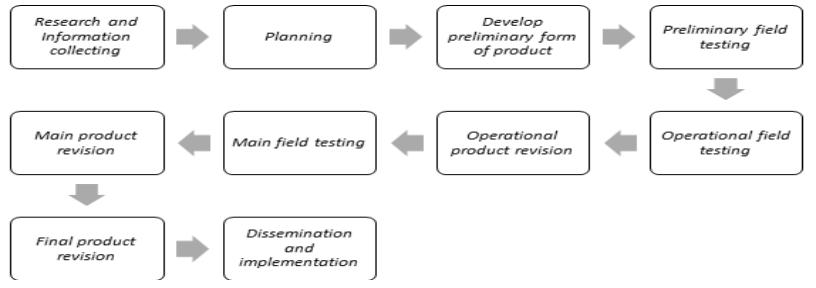

Figure 3.1. Source: Walter R. Borg and Meredith D. Gall, Educational Research: An Introduction, 4th Edition

(New York: Longman Inc., 1983), page. 775-776.

The dribbling training model on this soccer game that will be created is the result of problems found by researcher in the field so that through several observation and interview processes with questionnaires given by researcher to the trainer. Referring to the results of observations and interviews at the time of the field, researchers will try to provide solutions and problems that can be developed with a model of dribbling training on soccer games in NTB and in Indonesia, especially football for students of Fool in IKIP Mataram.

\subsection{Concept of Model Development}

the word "penelitian" comes from English "research", if it is parsed from this word, there are two words, namely, ' $R e^{\text {' }}$ interpreted "Lagi" and 'search' interpreted as"mencari", so "penelitian" is an activity to search, record, formulate, and analyze until compiling the report. Sugiyono (2013: 297) in his book says that research and development is research that is used to produce certain products, and test the effectiveness of these products. While according to Sukmadinata (2005: 164) also explains that research and development is a process or steps to develop a new product or perfect existing products, which can be justified. Development research is a systematic study to design, develop, and evaluate process programs and results.

Table 1.1. Research Design in Model Effectiveness Test.

\begin{tabular}{llll}
\hline Subject & Pre-test & Treatment & Post-test \\
\hline $\mathrm{R}$ & 01 & $\mathrm{P}$ & 02 \\
\hline
\end{tabular}

The design of the dribble training model with this game of soccer sports will be the main subject in the development of the driblle learning model, which is as follows: (1) 30 football players in a small group trial; (2) 70 football players in large group trials; and (3) 30 students will be involved in the effectiveness test. Students who are involved in each trial and effectiveness test are carried out in different groups. The sample was Fool student of IKIP Mataram. 
The steps taken in this trial include; (1) determining the group of research subjects; (2) implementing of pre-test $(\mathrm{O} 1)$; (3) trying the model that has been developed; (4) implementing of post-test (O2); (5) looking for the average score of the pre-test and post-test and comparing between the two; (6) looking for the difference in the second difference on average through the statistical method (t-test) to determine whether there is a significant effect of the use of the model or not.

The researcher obtained the results of skill data through the assessment of dribble instruments in soccer games as follows:

\subsection{Data Analysis}

To test the research hypothesis, statistics uses the T test with a pre-experimental research design of the one group pre-test-post-test design.

\section{Paired Samples Statistics}

\begin{tabular}{llllll}
\hline & Mean & N & Std. Deviation & Std. Error Mean \\
\hline Pair 1 & PRE_TE & 11.0667 & 30 & 1.70057 & .31048 \\
& ST & & & & \\
\cline { 2 - 5 } & POST_T & & & & \\
& & & & & \\
& EST & 9.7667 & 30 & 1.22287 & \\
\hline
\end{tabular}

Based on the results of the output using SPSS 21 that the average value before given is 11.0667 and after being given treatment with the football dribble training model is 9.7667, which means that the average value in there is an increase. The research uses bar charts in the training model which can be seen as follows:

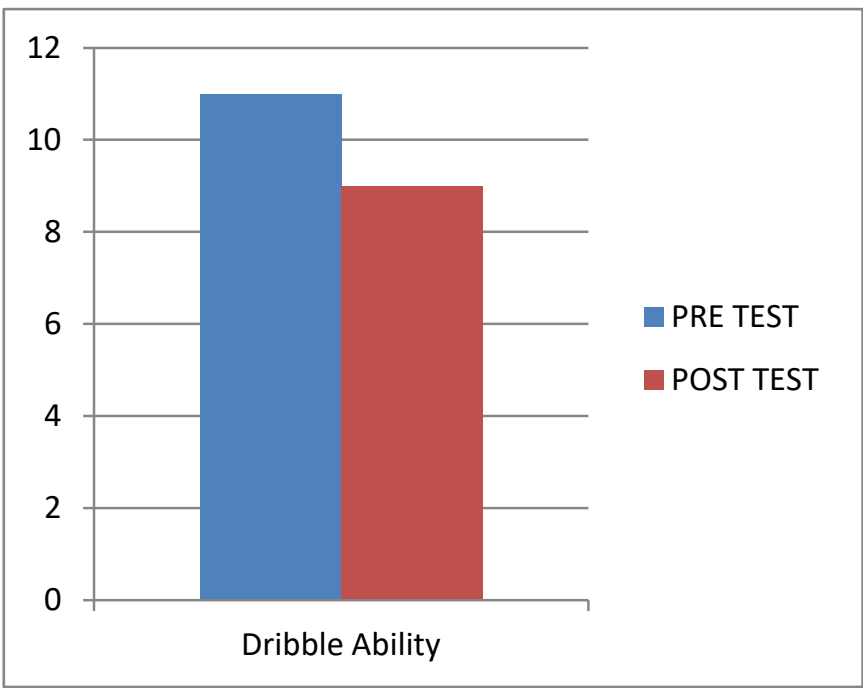

\section{RESULTS AND DISCUSSION}

\section{Normality test}

To test the normality of the data used the Kolmogorov Smirnov test, the calculation using the SPSS release 21 program (C.Trihendradi, 2013:193). If the calculation results obtained by probability (p) are greater than the level of error (0.05), then it indicates that the data is normally distributed. Based on the table above, the Kolmogorov Smirnov value for the pre-test and post-test data on the dribble training model in the game of football $\left(\mathrm{X}_{1}\right)$ is 0.921 with Asymp. Sig. (2-tailed) $=0.365>0.05$, and $\left(\mathrm{X}_{2}\right)$ amounting to 0.920 with Asymp. Sig. $(2$-tailed $)=0.366>$ 0.05 , which means that the distribution model is normal. Based on this analysis above, it shows that the two variable data are normally distributed.

The test results before and after being given treatment can be concluded that the dribble training model in football games is feasible and effective to improve the ability to grasp the ball. In testing the significance of differences with SPSS 21 obtained from the results of the data t-count $=8,510, \mathrm{df}=29$ and $\mathrm{p}$-value $=0.00<0.05$ which indicates that there is a significant difference between before and after the influence of the treatment of dribble training models on soccer games on students Fool in IKIP Mataram.

\section{CONCLUSION}

The implementation of this research model is planned to disseminate (dimensions) products that have been revised so that they have become the final results for soccer coaches through media or discussions and journals to be published. As a summative evaluation material, this product will be disseminated to the club / team in NTB especially football in Fool student of IKIP Mataram for a certain period of time, so that they can assess the effectiveness and efficiency of this product in the training process. Based on the results of the study it can be concluded that the dribble training model in the sepkabola game has a significant effectiveness. The dribble training model on soccer games was created by researchers to help trainers or teachers in varying skills training, as well as basic techniques, especially dribble increased as a reference exercise in students Fool in IKIP Mataram. This model is made on the basis of children's needs, especially in beginner athletes. This product after reviewing several weaknesses that need improvement, can be conveyed several advantages of this product include: 
a. Able to improve ability in all aspects of the technique

b. The dribble training model for soccer games is more effective and efficient. The model used is very varied which can increase the level of enthusiasm of athletes in training

c. Athletes can feel comfort and safety in the process of soccer training

d. This model can be Turbo booster motivation in children for special dribble techniques

e. As a reference for training at the Club

f. Can help coaches to train and find athletes

g. Contributions to science, especially training throughout Indonesia, especially for Fool students in IKIP Mataram.

\section{REFERENCES}

Borg W.R. \& Gall M.D. (1983). Education research. Fourth edition. New York: Longman Inc.

Cook Malcolm. (2013). Drills Sepak Bola untuk Pemain Muda. Jakarta: Indeks.

Danny Mielke. (2007). Dasar-dasar Sepak Bola. Bandung: PT. Intan Sejati.

Depdiknas. (2009). Himpunan peraturan perundang-undangan. Undang-undang sisdiknas tentang sistem pendidikan nasional. Bandung: Fokusmedia.

Hari Amirullah Rahman. (2008a).Dimensi kreatif dalam pembelajaran pendidikan jasmani di

Hari Amirullah Rahman. (2008b).Theories of learning/teori belajar. Terjemahan oleh. Tri Wibowo, B.S. Edisi ketujuh. Jakarta: PT. Kencana Prenada Media Group.

Hurlock (1996) dalam http://www.putrawijaya.co.cc di akses Senin, Juni 14, 2010, 4:05:58 PM

Jumesam. (2014). Pendidikan Jasmani Olahraga dan Kesehatan. Malang: Wineka Media.

Joyce B. \& Weil M. (1996a). Model of teaching. London: A Simon \& Schuster Company.

Joyce B. \& Weil M. (2009b). Model-model pengajaran. Terjemahan oleh achmad Fawaid \& Ateilla Mirza.Edisi Pertama.Yogyakarta: Pustaka Pelajar.

Sugiyono. (2010). Metode penelitian kuantitatif kualitatif dan R \& D. Bandung: Alfabeta.

Wasis D. Dwiyogo. (2009). Olahraga dan pembangunan. Malang: Wineka Media.

Widiastuti. (2011). Tes dan Pengukuran Olahraga. Jakarta: PT. Bumi Timur Jaya. 